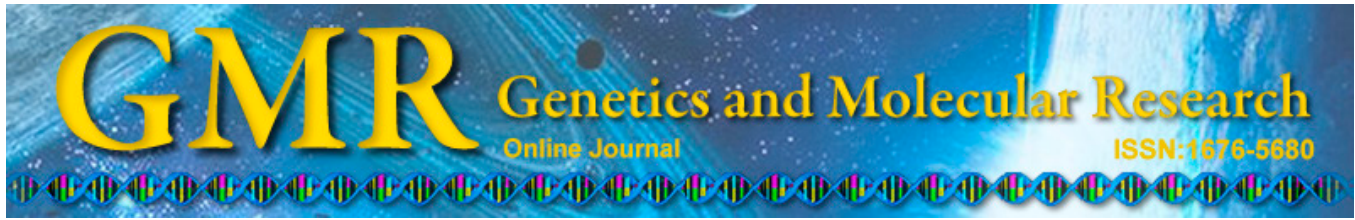

\title{
6-Dimethylaminopurine and cyclohexamide are mutagenic and alter reproductive performance and intrauterine development in vivo
}

\author{
R.J. Oliveira ${ }^{1,2,3,4}$, M.S. Mantovani ${ }^{5}$, J.R. Pesarini ${ }^{2,3}$, M.O. Mauro ${ }^{2,6}$, \\ A.F. da Silva ${ }^{5}$, T.R. Souza $^{7}$ and L.R. Ribeiro ${ }^{1,8}$ \\ ${ }^{1}$ Programa de Pós-Graduação em Biologia Celular e Molecular, \\ Instituto de Biociências de Rio Claro, Universidade Estadual Paulista, \\ Rio Claro, SP, Brasil \\ ${ }^{2}$ Centro de Estudos em Células-Tronco, Terapia Celular e Genética Toxicológica, \\ Núcleo de Hospital Universitário, Universidade Federal de Mato Grosso do Sul, \\ Campo Grande, MS, Brasil \\ ${ }^{3}$ Programa de Pós-Graduação em Saúde e Desenvolvimento na Região \\ Centro-Oeste, Faculdade de Medicina "Dr. Hélio Mandetta", \\ Universidade Federal de Mato Grosso do Sul, Campo Grande, MS, Brasil \\ ${ }^{4}$ Programa de Mestrado em Farmácia, Centro de Ciências Biológicas e da Saúde, \\ Universidade Federal de Mato Grosso do Sul, Campo Grande, MS, Brasil \\ ${ }^{5}$ Departamento de Biologia Geral, Universidade Estadual de Londrina, \\ Londrina, PR, Brasil \\ ${ }^{6}$ Programa de Doutorado em Biotecnologia e Biodiversidade - \\ Rede Pró Centro-Oeste, Universidade Federal de Mato Grosso do Sul, \\ Campo Grande, MS, Brasil \\ ${ }^{7}$ Centro de Estudos em Nutrição e Genética Toxicológica, \\ Centro Universitário Filadélfia, Londrina, PR, Brasil \\ ${ }^{8}$ Programa de Pós-Graduação em Patologia, Faculdade de Medicina de Botucatu, \\ Universidade Estadual Paulista, Botucatu, SP, Brasil \\ Corresponding author: R.J. Oliveira \\ E-mail: rodrigo.oliveira@ufms.br
}

Genet. Mol. Res. 14 (1): 834-849 (2015)

Received May 7, 2014

Accepted October 11, 2014

Published February 2, 2015

DOI http://dx.doi.org/10.4238/2015.February.2.8

ABSTRACT. The compounds 6-dimethylaminopurine (6-DMAP) and cyclohexamide (CHX) are currently used to stimulate the development 
of embryos produced by nuclear transfer in the production of cloned mammals with a great deal success. This study investigated the effects of 6-DMAP and CHX in vivo using biological assays to evaluate reproductive performance in females, teratogenesis, and mutagenesis. The results of this study demonstrated that the activating agents of oocyte cytoplasm, 6-DMAP and CHX, altered the reproductive performance of the experimental animals, as well as increased the rate malformations. In addition to these adverse effects, the administration of these compounds in pregnant females resulted in genotoxic and mutagenic toxicity, as determined by comet and micronucleus assays carried out in peripheral blood samples, respectively. Based on these findings and that alterations in DNA are important, morpho-functional teratogenesis and diminished embryonic viability, suggesting that 6-DMAP and CHX, which are utilized during the cloning of mammals, are responsible for the fact that embryos produced by nuclear transfer show low viability after implantation in utero or after birth because of congenital malformations and/or alterations in their DNA.

Key words: Comet assay; Cycloheximide; Somatic cell nuclear transfer; Mutagenicity; Teratogenicity

\section{INTRODUCTION}

Mutagenic and teratogenic events are correlated because both phenomena result from permanent alterations in DNA. These alterations can modify mitotic events involved in cell migration and cell differentiation, morphogenesis, and growth in an organism. According to Oliveira et al. (2009), mutations can lead to adverse phenotypes, reduction in fetal viability, and alterations in the reproductive performance of experimental animals.

It has been reported that $6-7 \%$ of primary congenital malformations result from chromosomal aberrations, while $7-8 \%$ are caused by mutated genes, $7-10 \%$ by environmental factors, $20-25 \%$ by multifactorial heredity, and $50-60 \%$ by unknown etiology (Schüler-Faccini et al., 2003).

High indices of spontaneous abortion are generally associated with high rates of congenital malformations. This correlation has also been observed during the cloning of mammals; in these cloning procedures, the rate of gestation up to 60 days is relatively high, and is close to $45 \%$ (Wells et al., 1999). However, the survival rate of embryos is less than $3 \%$ (Westhusin et al., 2001). This relationship does not appear to vary, even when different cell types are used, such as different types of nuclear donors involved in cloning by nuclear transfer (Hill et al., 1999).

The high rate of fetal losses during the gestation of cloned animals is thought to be associated with deficiencies in nuclear transfer to in vitro systems for the maturation and cultivation of embryos and because of alterations in donor cells. In the products of nuclear transfer, alterations such as abnormal placenta, failures in maternal-fetal communication, high birth weight, respiratory problems, defects in energy metabolism, renal dysfunction, thymic and lymphoid hypoplasia, and steatosis are frequently observed (Hill et al., 1999). 
The low viability of cloning techniques in mammals may be caused by chromosomal alterations observed using different protocols. De La Fuente and King (1998) found that 6-dimethylaminopurine (6-DMAP) and cyclohexamide (CHX) can be used to successfully produce mammalian clones, including cattle, rabbits, goats, and horses. 6-DMAP acts as a phosphorylation inhibitor and inducer of the inactivation of maturation promoting factor, while CHX is an inhibitor of protein synthesis. Despite satisfactory rates of activation, incidences of aneuploidy have been observed in embryos of different species when 6-DMAP is used.

An important advance in the area of cloning was the success of the nuclear transfer technique in the production of Rhesus monkeys. However, little is known regarding the efficacy of treatments for the activation of oocytes in these animals or the viability of these clones (Mitalipov et al., 2001). In addition, according to Mitalipov et al. (2001), harmful effects on DNA from the use of 6-DMAP and CHX have been observed, demonstrating the compromised development of oocytes in cattle.

Based on previous results and realizing that the future holds great promise for the use of cloning procedures by nuclear transfer in mammals, the aim of the present study was to evaluate the effects of 6-DMAP and CHX as mutagenic compounds capable of altering the reproductive performance and the intrauterine development of female mice exposed to these substances during organogenesis.

\section{MATERIAL AND METHODS}

\section{Chemical agents}

The compounds 6-DMAP (CAS No. 938-55-6, Sigma, St. Louis, MO, USA) and CHX (CAS No. 66-81-9; Sigma) were dissolved in sterile $\mathrm{Ca}^{+2}$ - and $\mathrm{Mg}^{+2}$-free phosphate-buffered saline, $\mathrm{pH}$ 7.4. The doses evaluated were $0.033,0.33$, and $3.30 \mathrm{mg} / \mathrm{kg}$ body weight (b.w.) for 6-DMAP and $0.053,0.53$, and $5.30 \mathrm{mg} / \mathrm{kg}$ (b.w.) for CHX, which were administered intraperitoneally (ip). The doses were established according to Oliveira et al. (2014).

\section{Animals}

Swiss mice (Mus musculus) of both sexes (105 females and 35 males) were utilized; they were of reproductive age, with a mean weight of $30 \mathrm{~g}$, and were obtained from the Central Bioterium of Universidade Estadual de Londrina. The experiments were conducted in the animal facility of the Departamento de Biologia Geral of the same institution. The animals were kept in polypropylene cages in groups of 3 in the case of females or in isolation in the case of males. The mice were allowed a minimal acclimation period of 7 days. Light and temperature were controlled using a 12-h photoperiod (12 h light: $12 \mathrm{~h}$ dark) with the temperature maintained around $22^{\circ} \pm$ $2{ }^{\circ} \mathrm{C}$ and a relative humidity of $55 \pm 10 \%$. Commercial ration (Nuvilab Products, PR, Brazil) and filtered water were provided ad libitum. The experiments were performed according to the guidelines of the Brazilian College of Animal Experimentation and approved by the Ethics Committee for Animal Experimentation of Universidade Estadual de Londrina (Protocol \#72/2005).

\section{Experimental design}

The animals were allowed to mate overnight at a proportion of 1 male: 3 females. Preg- 
nancy was determined by the detection of a vaginal plug, which was considered day 0 of gestation.

The animals were divided into 7 experimental groups $(\mathrm{N}=15)$. The mice in the control group (Group 1) received sterile $\mathrm{Ca}^{+2}$ - and $\mathrm{Mg}^{+2}$-free phosphate-buffered saline, $\mathrm{pH}$ 7.4, at a dose of $0.1 \mathrm{~mL} / 10.0 \mathrm{~g}$ b.w. (ip) during organogenesis (6-15th gestational day). Groups 2-4, which were treated with 6-DMAP, received daily doses of $0.033,0.33$, and $3.30 \mathrm{mg} / \mathrm{kg} \mathrm{b.w}$. (ip), respectively, during organogenesis. The groups treated with CHX (Groups 5-7) received doses of $0.053,0.53$, and $5.30 \mathrm{mg} / \mathrm{kg}$ b.w. (ip), respectively, following the above regimen.

\section{Biological assays}

\section{Reproductive performance and teratogenesis assays}

The gestational period was allowed to proceed up to the 18th day, when the females were euthanized by cervical dislocation to carry out laparotomy and to collect the fetuses and organs (lungs, heart, liver, and kidneys) to determine toxic maternal effects. Hysterectomy and umbilectomy were performed, recording the number of implantation sites according to the method of Salewski (1964), as well as occurrence of reabsorptions, number of live and dead fetuses, and fetal and placental weights. Systematic analyses were conducted to detect external fetal malformations and sexes. Next, the following parameters were determined: fertility rate (number of pregnant females x 100/number of mated females); rate of premature births (number of births before the 18th gestational day x 100/number of mated females); abortion rate (number of females that aborted x 100/number of mated females); rate of false positives (number of nonpregnant females in which a vaginal plug was identified x 100/number of mated females); percentage of females used for teratological studies [\%PFTS $=$ fertility rate - (premature birth rate + abortion rate + false positive rate)]; sex ratio (number of male fetuses/number of female fetuses); reabsorption rate (number of reabsorptions x 100/number of implantations); rate of post-implantational losses (number of implantations - number of live fetuses x 100/number of implantations); placental index (placental weight/fetal weight); and the rate of external/visceral/skeletal malformations (number of malformed fetuses x 100/ number of fetuses examined). Adequate fetal weight for gestation age was determined according to the method of Oliveira et al. (2009). The fetuses were classified as: fetus with adequate weight for gestation age, indicating a fetus weight within the mean fetal weight of the control group plus or minus the standard deviation; fetus with low weight for gestation age, indicating a fetus with a body weight lower than the mean of the control minus the standard deviation; or fetus with high weight for gestation age, representing a fetus with a body weight above the mean of the control group plus the standard deviation.

The offspring were divided randomly into 2 subgroups, each of which included half of the litter. Fetuses in the first group were fixed in Bodian's solution and subjected to visceral analysis by sectioning/microdissection as described by Barrow and Taylor (1969) to study the thorax and abdomen and strategic sections were produced as described by Wilson (1965) to study the head, with modifications as suggested by Damasceno et al. (2008) and Oliveira et al. (2009). The classification of visceral alterations was based principally on studies by Taylor (1986), Manson and Kang (1994), Damasceno et al. (2008), and Oliveira et al. (2009). The second subgroup was designated for skeletal analysis as described by Staples and Schnell (1964). Classification of skeletal alterations was carried out according to Taylor (1986), Manson et al. (1994), Damasceno et al. (2008), and Oliveira et al. (2009). Examination of the fetal 
viscera and skeleton was performed using a stereo magnifying glass (SMZ 140, Motic, Hong Kong, China) at $4 \mathrm{X}$ magnification.

\section{Comet assay}

Peripheral blood was drawn by tail vein puncture from 7 pregnant animals per experimental group $4 \mathrm{~h}$ after the first administration of the compounds to evaluate genotoxicity.

Comet assays were performed according as described by Singh et al. (1988) and Tice et al. (2000) with modifications.

Slides were prepared by depositing $20 \mu \mathrm{L}$ cell suspension with $120 \mu \mathrm{L}$ low-melting point agarose $(1.5 \%)$ at $37^{\circ} \mathrm{C}$ on slides pre-coated with normal agarose $(5 \%)$. The slides with cells were then cover-slipped and cooled at $4^{\circ} \mathrm{C}$ for $20 \mathrm{~min}$ and subsequently immersed in lysis solution for $1 \mathrm{~h}$. Next, the cells were transferred to electrophoresis buffer for $20 \mathrm{~min}$ for denaturation and then subjected to electrophoresis in buffer at $\mathrm{pH}>13.0$ at $4^{\circ} \mathrm{C}$ for $20 \mathrm{~min}$. The slides were then neutralized, air-dried, and fixed in absolute ethanol for $10 \mathrm{~min}$.

The slides were stained with $100 \mu \mathrm{L}$ ethidium bromide $(20 \mu \mathrm{g} / \mathrm{mL})$. The material was evaluated under a fluorescence microscope (Nikon, Tokyo, Japan) at 400X magnification with an excitation filter of $420-490 \mathrm{~nm}$ and a barrier filter of $520 \mathrm{~nm}$.

A total of 100 cells were examined per treatment, and the comets were classified as follows: class 0 , cells with no tail; class 1 , cells with a tail length shorter than the diameter of the nucleus; class 2, cells with a tail size between 1 and 2 times the diameter of the nucleus; and class 3, cells with a tail size greater than 2 times the diameter of the nucleus. Apoptotic cells with a completely fragmented nucleus were not counted (Kobayashi et al., 1995).

The total score was calculated as the sum of the values resulting from the multiplication of the total cells observed in each class of lesion by the class value (0-3).

\section{Micronucleus test in peripheral blood}

The same animals evaluated for genotoxicity were also subjected to peripheral blood sampling to evaluate mutagenicity at 2 different time points. Blood was collected at times T1 and T2, which were $24 \mathrm{~h}$ after the first administration of the test compounds (7th gestational day) and $24 \mathrm{~h}$ after the last administration (16th gestational day), respectively.

Mutagenicity was evaluated using the micronucleus technique in peripheral blood samples as described by Hayashi et al. (1990) with some modifications. A drop of blood was placed on a slide previously coated with a layer of $1.0 \mathrm{mg} / \mathrm{mL}$ acridine orange. The slide was then cover-slipped and placed at $-20^{\circ} \mathrm{C}$ for at least 2 weeks. A total of 2000 cells/animal were inspected under a fluorescence microscope (Nikon) at 400X magnification with a 420-490 nm excitation filter and $520 \mathrm{~nm}$ barrier filter.

\section{Statistical analysis}

Parametric and non-parametric tests (analysis of variance, Kruskal-Wallis, and chisquared) were utilized to compare quantitative data related to reproductive performance and teratogenicity assays, depending on the data distribution. For qualitative data and frequencies obtained, the litter was utilized as the unit base, as recommended in the literature in this field (Haseman and Hogan, 1975; Manson et al., 1982). Data from the genotoxicity and mutagenic- 
ity assays were evaluated utilizing analysis of variance followed by the Tukey-Kramer test to compare the means of damaged cells and the distribution among the classes of DNA damage, scores in the comet assay, and mean frequencies of the micronucleus test in peripheral blood. In all cases, the difference was considered to be statistically significant when $\mathrm{P}<0.05$.

\section{RESULTS}

\section{Reproductive performance and teratogenesis}

Table 1 presents the parameters related to mating, fertility rate, premature births, abortions, and false-positives of females treated with the test compounds. Based on statistical analysis, there were no significant differences between the controls and groups treated with 6-DMAP and CHX with respect to fertility rate, premature birth rate, rate of abortions, or rate of false-positives. The occurrence of premature births was associated with the 2 lower doses of 6-DMAP and CHX. In addition, abortions occurred with the highest doses of 6-DMAP used and with all doses of CHX. The effects of CHX treatment were characterized by a doseresponse curve for this parameter, and the occurrence of abortion was directly proportional to dose. Thus, the variation in the rate of abortion was $6.7-20.0 \%$ among the groups receiving this compound.

Table 1. Parameters related to mating, fertility rates, premature birth, abortion, and false-positive pregnancies of females treated with 6-dimethylaminopurine (6-DMAP) and cycloheximide (CHX).

\begin{tabular}{|c|c|c|c|c|c|c|c|}
\hline \multirow[t]{3}{*}{ Parameters } & \multicolumn{7}{|c|}{ Experimental groups } \\
\hline & \multirow{2}{*}{$\frac{\text { Control (PBS) }}{0.1 \mathrm{~mL} / 10 \mathrm{~g}}$} & \multicolumn{3}{|c|}{ 6-DMAP } & \multicolumn{3}{|c|}{$\mathrm{CHX}$} \\
\hline & & $0.033 \mathrm{mg} / \mathrm{kg}$ & $0.33 \mathrm{mg} / \mathrm{kg}$ & $3.30 \mathrm{mg} / \mathrm{kg}$ & $0.053 \mathrm{mg} / \mathrm{kg}$ & $0.53 \mathrm{mg} / \mathrm{kg}$ & $5.30 \mathrm{mg} / \mathrm{kg}$ \\
\hline \multicolumn{8}{|c|}{ Parameters related to mating } \\
\hline Mating & 15 & 15 & 15 & 15 & 15 & 15 & 15 \\
\hline Fertil. rate $(\%)$ & $86.7^{\mathrm{a}}$ & $86.7^{\mathrm{a}}$ & $86.7^{\mathrm{a}}$ & $86.7^{\mathrm{a}}$ & $86.7^{\mathrm{a}}$ & $100.0^{\mathrm{a}}$ & $93.3^{\mathrm{a}}$ \\
\hline \%PFTS (ANL) & $66.7(10)$ & $73.3(11)$ & $73.3(11)$ & $66.7(10)$ & $66.7(10)$ & $86.7(12)$ & $73.3(11)$ \\
\hline Rate. pre. births (\%) & $0.0^{\mathrm{a}}$ & $6.7^{\mathrm{a}}$ & $0.0^{\mathrm{a}}$ & $0.0^{\mathrm{a}}$ & $6.7^{\mathrm{a}}$ & $0.0^{\mathrm{a}}$ & $0.0^{\mathrm{a}}$ \\
\hline Rate abo. (\%) & $0.0^{\mathrm{a}}$ & $0.0^{\mathrm{a}}$ & $0.0^{\mathrm{a}}$ & $20.0^{\mathrm{a}}$ & $6.7^{\mathrm{a}}$ & $13.3^{\mathrm{a}}$ & $20.0^{\mathrm{a}}$ \\
\hline Rate fal. pos. (\%) & $20.0^{\mathrm{a}}$ & $6.7^{\mathrm{a}}$ & $13.3^{\mathrm{a}}$ & $0.0^{\mathrm{a}}$ & $6.7^{\mathrm{a}}$ & $0.0^{\mathrm{a}}$ & $0.0^{\mathrm{a}}$ \\
\hline
\end{tabular}

Mating = number of mating females; Fertil. rate $=$ fertility rate (number pregnant females $\mathrm{x}$ 100/number mating females); $\%$ PFTS $=$ percentage of females for teratology studies $=$ fertil. rate $=($ rate pre. births + rate abo. + rate fal. pos.); $\mathrm{ANL}=$ absolute number of litters; Rate. pre. births = rate of premature births (number of births prior to 18 gestational days $\mathrm{x}$ 100/number mating females); Rate abor. $=$ rate of abortion (number females who underwent abortion x 100/number mating females); Rate fal. pos. = rate of false positives (number of non-pregnant females, in which a vaginal plug was identified x 100/number of mating females). Different letters indicate statistically significant differences. Statistical test: chi-square $(\mathrm{P}<0.05)$.

Parameters related to the development of body weight and the weight of organs in females are described in Table 2. Statistical analysis indicated that at the beginning of the experiments, the animals had similar weights. There were also no significant differences evident on day 0 of gestation. At the end of the gestational period, a substantial decrease was noted in the weight of females treated with the highest dose of CHX compared to the other groups, which was also found for the weight of the pregnant uterus. In addition, reduced weight gain and wet weight gain was generally observed for animals in this group. 


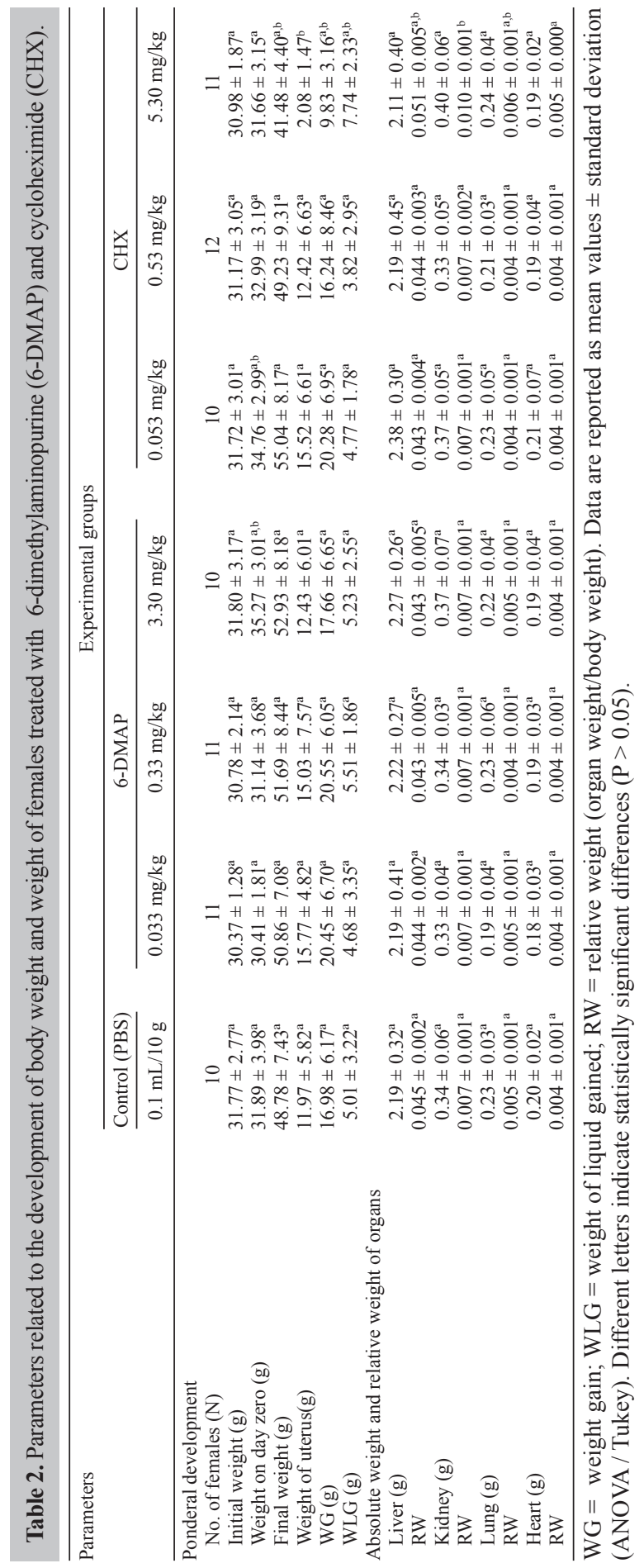


Regarding the absolute weight of the organs, including the liver, kidneys, lungs, and heart, no statistically significant differences were observed. This was also true for the relative weight of the heart. However, for the relative weights of other organs, there was an increase in the females treated with the highest dose of CHX.

Table 3 presents data related to reproductive parameters. Statistical analysis revealed no statistically significant differences between the control and treated groups for the number of implants, number of live fetuses, numbers of male and female fetuses, sex ratio, placental weight, placental index, and rate of external and skeletal malformations.

\begin{tabular}{|c|c|c|c|c|c|c|c|}
\hline \multirow[t]{3}{*}{ Parameters } & \multicolumn{7}{|c|}{ Experimental groups } \\
\hline & \multirow{2}{*}{$\begin{array}{c}\text { Control (PBS) } \\
0.1 \mathrm{~mL} / 10 \mathrm{~g}\end{array}$} & \multicolumn{3}{|c|}{ 6-DMAP } & \multicolumn{3}{|c|}{ CHX } \\
\hline & & $0.033 \mathrm{mg} / \mathrm{kg}$ & $0.33 \mathrm{mg} / \mathrm{kg}$ & $3.30 \mathrm{mg} / \mathrm{kg}$ & $0.053 \mathrm{mg} / \mathrm{kg}$ & $0.53 \mathrm{mg} / \mathrm{kg}$ & $5.30 \mathrm{mg} / \mathrm{kg}$ \\
\hline \multicolumn{8}{|l|}{ Reproductive parameters } \\
\hline Number of females $(\mathrm{N})$ & 10 & 11 & 11 & 10 & 10 & 12 & 11 \\
\hline Implants $^{1}$ & $8.60 \pm 4.58^{\mathrm{a}}$ & $11.00 \pm 2.68^{\mathrm{a}}$ & $11.27 \pm 3.78^{\mathrm{a}}$ & $10.10 \pm 4.38^{\mathrm{a}}$ & $12.00 \pm 3.23^{\mathrm{a}}$ & $9.46 \pm 4.16^{\mathrm{a}}$ & $9.00 \pm 3.90^{\mathrm{a}}$ \\
\hline Reabsorptions $^{1}$ & $1.80 \pm 2.10^{\mathrm{a}}$ & $2.00 \pm 1.95^{\mathrm{a}}$ & $2.27 \pm 2.53^{\mathrm{a}}$ & $1.90 \pm 2.38^{\mathrm{a}}$ & $2.90 \pm 3.03^{\mathrm{a}}$ & $2.07 \pm 2.50^{\mathrm{a}}$ & $8.36 \pm 3.67^{b}$ \\
\hline Live fetuses ${ }^{1}$ & $6.80 \pm 3.42^{\mathrm{a}}$ & $9.00 \pm 2.93^{\mathrm{a}}$ & $8.82 \pm 4.92^{\mathrm{a}}$ & $8.20 \pm 4.05^{\mathrm{a}}$ & $9.10 \pm 4.01^{\mathrm{a}}$ & $8.00 \pm 3.72^{\mathrm{a}}$ & $2.33 \pm 0.58^{\mathrm{a}}$ \\
\hline \multirow[t]{2}{*}{ Fetal weight $(\mathrm{g})^{1}$} & $1.41 \pm 0.13^{\mathrm{a}}$ & $1.40 \pm 0.15^{\mathrm{a}}$ & $1.38 \pm 0.11^{\mathrm{a}}$ & $1.24 \pm 0.33^{\mathrm{a}}$ & $1.32 \pm 0.07^{\mathrm{a}}$ & $1.30 \pm 0.14^{\mathrm{a}}$ & $0.77 \pm 0.06^{\mathrm{b}}$ \\
\hline & HWGA & AWGA & AWGA & LWGA & AWGA & AWGA & LWGA \\
\hline Fetal len. $(\mathrm{cm})^{1}$ & $2.56 \pm 0.12^{\mathrm{a}}$ & $2.59 \pm 0.07^{\mathrm{a}}$ & $2.54 \pm 0.11^{\mathrm{a}}$ & $2.41 \pm 0.31^{\mathrm{a}}$ & $2.54 \pm 0.10^{\mathrm{a}}$ & $2.56 \pm 0.16^{\mathrm{a}}$ & $2.04 \pm 0.11^{\mathrm{b}}$ \\
\hline Fetuses $\widehat{\partial}(\mathrm{AN})$ & $4.10 \pm 2.02^{\mathrm{a}}(41)$ & $5.36 \pm 2.73^{\mathrm{a}}(59)$ & $4.91 \pm 2.55^{\mathrm{a}}(54)$ & $4.20 \pm 2.66^{\mathrm{a}}(42)$ & $4.60 \pm 3.13^{\mathrm{a}}(46)$ & $3.83 \pm 2.52^{\mathrm{a}}(46)$ & $0.33 \pm 0.58^{\mathrm{a}}$ \\
\hline Fetuses + $(\mathrm{AN})$ & $2.70 \pm 1.89^{\mathrm{a}}(27)$ & $3.64 \pm 2.80^{\mathrm{a}}(40)$ & $4.09 \pm 2.98^{\mathrm{a}}(45)$ & $3.90 \pm 2.51^{\mathrm{a}}(39)$ & $4.50 \pm 1.41^{\mathrm{a}}(45)$ & $4.17 \pm 2.66^{\mathrm{a}}(50)$ & $2.00 \pm 1.00^{\mathrm{a}}(6)$ \\
\hline Sex ratio & $1.61 \pm 0.83^{\mathrm{a}}$ & $2.16 \pm 2.08^{\mathrm{a}}$ & $1.03 \pm 0.31^{\mathrm{a}}$ & $1.41 \pm 1.12^{\mathrm{a}}$ & $0.95 \pm 0.67^{\mathrm{a}}$ & $1.17 \pm 0.86^{\mathrm{a}}$ & $0.33 \pm 0.58^{\mathrm{a}}$ \\
\hline Plac. weigth $(g)^{1}$ & $0.19 \pm 0.22^{\mathrm{a}}$ & $0.10 \pm 0.01^{\mathrm{a}}$ & $0.11 \pm 0.02^{\mathrm{a}}$ & $0.12 \pm 0.03^{\mathrm{a}}$ & $0.12 \pm 0.02^{\mathrm{a}}$ & $0.11 \pm 0.02^{\mathrm{a}}$ & $0.09 \pm 0.00^{\mathrm{a}}$ \\
\hline Rate PIL $(\%)^{2}$ & $17.51 \pm 5.55^{\mathrm{a}}$ & $18.41 \pm 4.95^{\mathrm{a}}$ & $23.77 \pm 8.48^{\mathrm{a}}$ & $16.00 \pm 6.77^{\mathrm{a}}$ & $26.20 \pm 9.27^{\mathrm{a}}$ & $20.95 \pm 8.21^{\mathrm{a}}$ & $94.26 \pm 3.00^{\mathrm{b}}$ \\
\hline Rate reabs. $(\%)^{2}$ & $17.51 \pm 5.55^{\mathrm{a}}$ & $18.41 \pm 4.95^{\mathrm{a}}$ & $23.77 \pm 8.48^{\mathrm{a}}$ & $16.00 \pm 6.77^{\mathrm{a}}$ & $26.20 \pm 9.27^{\mathrm{a}}$ & $20.95 \pm 8.21^{\mathrm{a}}$ & $94.26 \pm 3.00^{\mathrm{b}}$ \\
\hline Placental index ${ }^{1}$ & $1.14 \pm 0.18^{\mathrm{a}}$ & $0.07 \pm 0.01^{\mathrm{a}}$ & $0.08 \pm 0.01^{\mathrm{a}}$ & $0.11 \pm 0.05^{\mathrm{a}}$ & $0.09 \pm 0.01^{\mathrm{a}}$ & $0.08 \pm 0.02^{\mathrm{a}}$ & $0.11 \pm 0.01^{\mathrm{a}}$ \\
\hline Rate ext. malf. ${ }^{2}$ & $0.00 \pm 0.00^{\mathrm{a}}$ & $10.86 \pm 4.49^{\mathrm{a}}$ & $3.18 \pm 2.36^{\mathrm{a}}$ & $12.40 \pm 6.84^{\mathrm{a}}$ & $12.86 \pm 10.09^{\mathrm{a}}$ & $5.83 \pm 2.37^{\mathrm{a}}$ & $27.78 \pm 14.70^{\mathrm{a}}$ \\
\hline Rate visc. malf. $^{2}$ & $0.00 \pm 0.00^{\mathrm{a}}$ & $48.35 \pm 8.79^{b}$ & $50.30 \pm 12.85^{\mathrm{b}}$ & $43.40 \pm 12.01^{\mathrm{ab}}$ & $41.35 \pm 11.24^{\mathrm{a}, \mathrm{b}}$ & $46.22 \pm 11.58^{\mathrm{a}, \mathrm{b}}$ & $80.00 \pm 20.00^{b}$ \\
\hline Rate ske. malf. ${ }^{2}$ & $70.00 \pm 13.12^{\mathrm{a}}$ & $87.88 \pm 6.39^{\mathrm{a}}$ & $70.30 \pm 10.36^{\mathrm{a}}$ & $100.00 \pm 0.00^{\mathrm{a}}$ & $83.70 \pm 10.84^{\mathrm{a}}$ & $66.48 \pm 10.04^{\mathrm{a}} \quad 1$ & $100.00 \pm 0.00^{\mathrm{a}}$ \\
\hline
\end{tabular}

${ }^{1}$ Mean values \pm standard deviation (analysis of variance/Tukey). ${ }^{2}$ Mean values \pm standard error (Kruskal-Wallis/ Dunn); HWGA = fetus with high weight for gestation age; AWGA = fetus with adequate weight for gestation age; LWGA = fetus with low weight for gestation age; Fetal len. = fetal length; $\mathrm{AN}=$ absolute number; Plac. weigth $=$ placental weight; Rate PIL $=$ rate of post-implantation losses; Rate reabs. $=$ rate of reabsorption; Rate ext. malf. $=$ rate external malformations. Rate visc. malf. $=$ rate visceral malformations. Rate ske. malf. $=$ rate skeletal malformations. Different letters indicate statistically significant differences $(\mathrm{P}<0.05)$.

When evaluating the number of reabsorptions, fetal weight, fetal length, rate of postimplantational losses, and rate of reabsorption, statistically significant changes were observed in the group treated with the highest dose of CHX compared to other groups. In addition, a diminution in fetal weight and length was observed, and these 2 parameters were related to low weight for gestational age. Although there were no significant alterations in fetal weight and length following treatment with the highest dose of 6-DMAP, the offspring of females who received this treatment showed low weight at birth.

When examining the rate of visceral malformation, we observed an increase in the occurrence of malformations in all groups treated with both compounds. However, the groups showing the highest frequency of malformations with statistically significant differences were the offspring of females treated with the 2 lower doses of 6-DMAP and the highest dose of CHX. 
Table 4 presents the relationships among and frequency of the external and visceral malformations observed following different treatments. The most frequent external malformations seen were fetuses born with closed eyes, exophthalmia, enlarged tongue (macroglossia), retromicrognathism, cleft palate, gastroschisis, phocomelia, and short tails. Visceral malformations included hydrocephalia, microphthalmia, esophageal atresia, tracheal atresia, thymic atresia, cardiomegaly, hydronephrosis, renal dysplasia, renal agenesis, and gonadal agenesis.

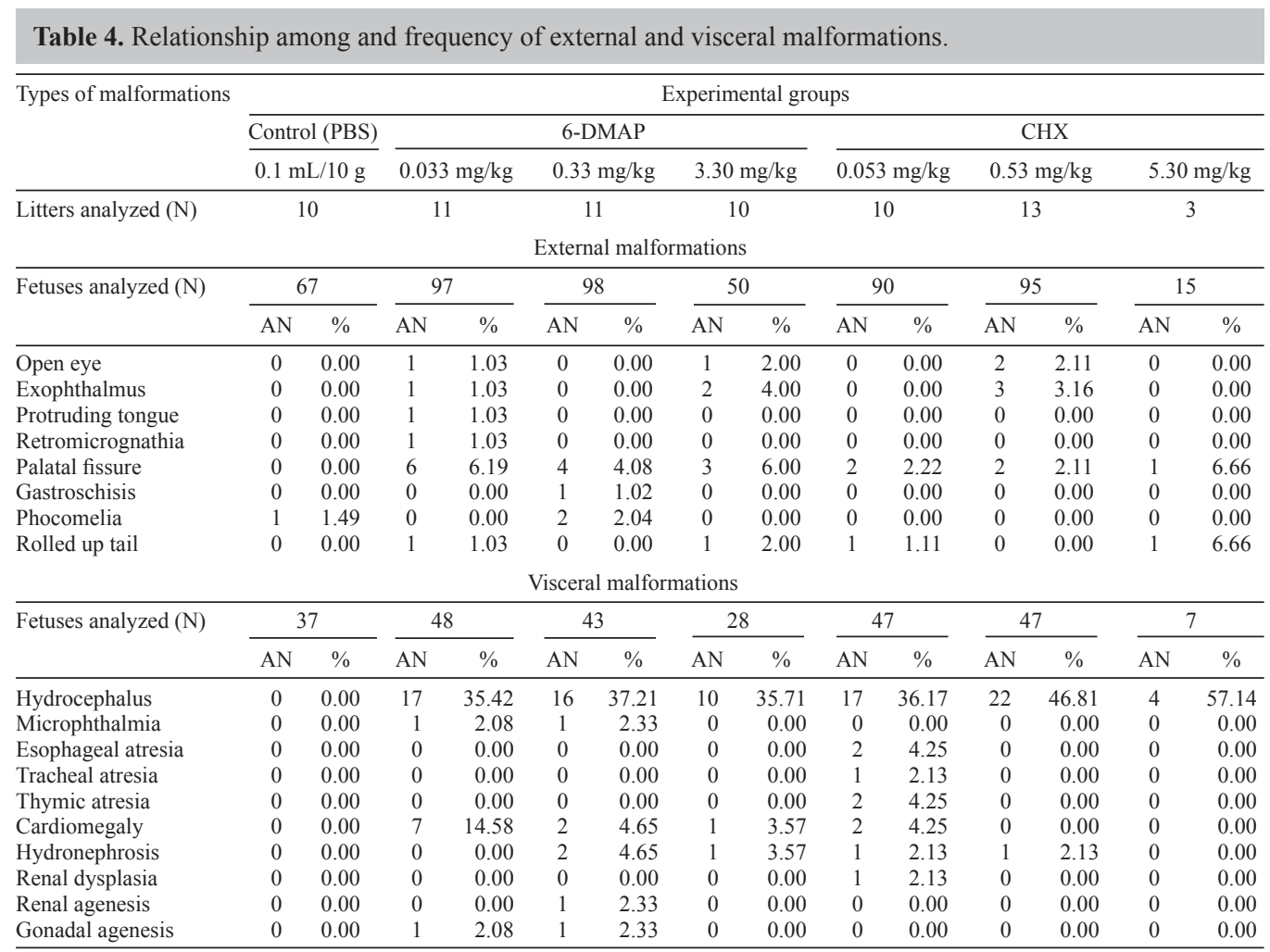

$\mathrm{AN}=$ absolute number of fetuses with a malformation; $\%=$ percentage of fetuses with the malformation.

Table 5 shows the relationship among and the frequency of skeletal malformations. In the cranium, alterations included reduced ossification of the pterygoid, basisphenoid, frontal, parietal, and interparietal bones, the absence of the tympanic annulus, and cleft palate. In the forelimbs, malformations observed included reduced ossification and the absence of metacarpals, distal and proximal phalanges, and syndactyly. In the hindlimbs, abnormalities included retroversion of the limbs and paws, reduced ossification, and absence of the metatarsals, distal and proximal phalanges, and a fifth of the ossification at the level of the proximal phalange.

Alterations of the sternum were very diverse, and some sternebrae were absent, poorly ossified, asymmetric, fused, or duplicated.

With respect to the vertebrae, there was an absence of cervical vertebrae, supranumerary cervical vertebrae, reduced ossification of the lumbar vertebrae, and reduced ossification of the sacral and coccygeal vertebrae. 
Table 5. Relationship among and frequency of skeletal malformations.

\begin{tabular}{|c|c|c|c|c|c|c|c|c|c|c|c|c|c|c|}
\hline \multirow[t]{3}{*}{ Types of malformations } & \multicolumn{14}{|c|}{ Experimental groups } \\
\hline & \multirow{2}{*}{\multicolumn{2}{|c|}{$\frac{\text { Control (PBS) }}{0.1 \mathrm{~mL} / 10 \mathrm{~g}}$}} & \multicolumn{6}{|c|}{ 6-DMAP } & \multicolumn{6}{|c|}{ CHX } \\
\hline & & & \multicolumn{2}{|c|}{$0.033 \mathrm{mg} / \mathrm{kg}$} & \multicolumn{2}{|c|}{$0.33 \mathrm{mg} / \mathrm{kg}$} & \multicolumn{2}{|c|}{$3.30 \mathrm{mg} / \mathrm{kg}$} & \multicolumn{2}{|c|}{$0.053 \mathrm{mg} / \mathrm{kg}$} & \multicolumn{2}{|c|}{$0.53 \mathrm{mg} / \mathrm{kg}$} & \multicolumn{2}{|c|}{$5.30 \mathrm{mg} / \mathrm{kg}$} \\
\hline Litters analyzed $(\mathrm{N})$ & \multicolumn{2}{|c|}{10} & \multicolumn{2}{|c|}{11} & \multicolumn{2}{|c|}{11} & \multicolumn{2}{|c|}{10} & \multicolumn{2}{|c|}{10} & \multicolumn{2}{|c|}{13} & \multicolumn{2}{|r|}{3} \\
\hline \multicolumn{15}{|c|}{ Skeletal malformations } \\
\hline \multirow[t]{2}{*}{ Fetuses analyzed $(\mathrm{N})$} & \multicolumn{2}{|c|}{30} & & 49 & & 55 & & 22 & & 3 & & 48 & & 8 \\
\hline & AN & $\%$ & AN & $\%$ & AN & $\%$ & $\mathrm{AN}$ & $\%$ & $\mathrm{AN}$ & $\%$ & $\mathrm{AN}$ & $\%$ & $\mathrm{AN}$ & $\%$ \\
\hline Skull & & & & & & & & & & & & & & \\
\hline Pterigoid RO & 0 & 0.00 & 0 & 0.00 & 0 & 0.00 & 0 & 0.00 & 0 & 0.00 & 0 & 0.00 & 3 & 37.50 \\
\hline Basisphenoid RO & 0 & 0.00 & 0 & 0.00 & 0 & 0.00 & 0 & 0.00 & 0 & 0.00 & 0 & 0.00 & 3 & 37.50 \\
\hline Abscence of tympanic annulus & 0 & 0.00 & 0 & 0.00 & 0 & 0.00 & 0 & 0.00 & 0 & 0.00 & 0 & 0.00 & 3 & 37.50 \\
\hline Frontal RO & 0 & 0.00 & 0 & 0.00 & 1 & 1.82 & 0 & 0.00 & 0 & 0.00 & 0 & 0.00 & 0 & 0.00 \\
\hline Parietal RO & 1 & 3.33 & 1 & 2.04 & 1 & 1.82 & 3 & 13.64 & 0 & 0.00 & 1 & 2.08 & 0 & 0.00 \\
\hline Interparietal RO & 2 & 6.67 & 2 & 4.08 & 3 & 5.45 & 4 & 18.18 & 0 & 0.00 & 1 & 2.08 & 3 & 37.50 \\
\hline Palatal fissure & 0 & 0.00 & 0 & 0.00 & 0 & 0.00 & 0 & 0.00 & 0 & 0.00 & 1 & 2.08 & 8 & 100.00 \\
\hline Forelimbs & & & & & & & & & & & & & & \\
\hline Metacarpals & 0 & 0.00 & 3 & 6.12 & 0 & 0.00 & 0 & 0.00 & 0 & 0.00 & 1 & 2.08 & 8 & 100.00 \\
\hline Distal phalanges & 10 & 33.33 & 13 & 26.52 & 3 & 5.45 & 9 & 40.91 & 17 & 39.53 & 18 & 37.50 & 3 & 37.50 \\
\hline Proximal phalanges & 5 & 16.65 & 13 & 26.52 & 6 & 10.91 & 6 & 27.27 & 11 & 25.58 & 9 & 18.75 & 3 & 37.50 \\
\hline Sindactilia & 0 & 0.00 & 0 & 0.00 & 0 & 0.00 & 1 & 4.54 & 0 & 0.00 & 0 & 0.00 & 0 & 0.00 \\
\hline Hindlimbs & & & & & & & & & & & & & & \\
\hline Retroversion of hindlimbs & 0 & 0.00 & 1 & 2.04 & 0 & 0.00 & 1 & 4.54 & 0 & 0.00 & 0 & 0.00 & 0 & 0.00 \\
\hline Retroversion of hindpaws & 0 & 0.00 & 0 & 0.00 & 2 & 3.64 & 0 & 0.00 & 0 & 0.00 & 0 & 0.00 & 0 & 0.00 \\
\hline Metatarsals & 0 & 0.00 & 3 & 6.12 & 0 & 0.00 & 4 & 18.18 & 0 & 0.00 & 0 & 0.00 & 8 & 100.00 \\
\hline Distal phalanges & 1 & 3.33 & 7 & 14.28 & 10 & 18.18 & 6 & 27.27 & 13 & 30.23 & 9 & 18.75 & 0 & 0.00 \\
\hline Proximal phalanges & 1 & 3.33 & 10 & 20.41 & 7 & 12.73 & 9 & 40.91 & 12 & 27.91 & 6 & 12.50 & 3 & 37.50 \\
\hline Ossification 5th Proximal phalange & 2 & 6.67 & 8 & 16.32 & 4 & 7.27 & 5 & 22.73 & 13 & 30.23 & 3 & 6.25 & 0 & 0.00 \\
\hline Sternum & & & & & & & & & & & & & & \\
\hline Sternebrae & 16 & 53.28 & 27 & 55.10 & 27 & 49.10 & 19 & 86.36 & 19 & 44.19 & 20 & 41.67 & 8 & 100.00 \\
\hline Vertebrae & & & & & & & & & & & & & & \\
\hline Absence of a cervical vertebrae & 0 & 0.00 & 1 & 2.04 & 0 & 0.00 & 0 & 0.00 & 0 & 0.00 & 0 & 0.00 & 0 & 0.00 \\
\hline Cervical vertebrae Supranumber & 0 & 0.00 & 0 & 0.00 & 0 & 0.00 & 0 & 0.00 & 0 & 0.00 & 1 & 2.08 & 3 & 37.50 \\
\hline Lumbar vertebrae RO & 0 & 0.00 & 0 & 0.00 & 0 & 0.00 & 3 & 13.64 & 0 & 0.00 & 0 & 0.00 & 8 & 100.00 \\
\hline Sacral and coccygeal vertebrae RO & 0 & 0.00 & 8 & 16.32 & 4 & 7.27 & 6 & 27.27 & 0 & 0.00 & 2 & 4.17 & 0 & 0.00 \\
\hline Ribs & & & & & & & & & & & & & & \\
\hline Assymetric axis & 0 & 0.00 & 0 & 0.00 & 0 & 0.00 & 0 & 0.00 & 0 & 0.00 & 1 & 2.08 & 0 & 0.00 \\
\hline LO cervical vertebrae - RR & 3 & 10.00 & 2 & 4.08 & 4 & 7.27 & 0 & 0.00 & 6 & & 0 & 0.00 & 0 & 0.00 \\
\hline Vertebrae chest - RR & 0 & 0.00 & 0 & 0.00 & 1 & 1.82 & 0 & 0.00 & 1 & 2.33 & 0 & 0.00 & 0 & 0.00 \\
\hline Vertebrae chest - rib RO & 1 & 3.33 & 1 & 2.04 & 1 & 1.82 & 4 & 18.18 & 2 & 4.65 & 0 & 0.00 & 0 & 0.00 \\
\hline LO lumbar vertebrae - Supranumber rib & 0 & 0.00 & 1 & 2.04 & 0 & 0.00 & 0 & 0.00 & 1 & 2.33 & 2 & 4.17 & 3 & 37.50 \\
\hline LO sacral vertebrae & 6 & 19.98 & 6 & 21.24 & 1 & 1.82 & 0 & 0.00 & 6 & 13.95 & 1 & 2.08 & 0 & 0.00 \\
\hline
\end{tabular}

$\mathrm{AN}=$ absolute number of fetuses with a malformation; $\%=$ percentage of fetus with malformation; $\mathrm{RO}=$ reduced ossification; $\mathrm{LO}=$ lateral ossification; $\mathrm{RR}=$ rudimentary rib.

At the level of the ribs, there was evidence of an asymmetric axis, cervical vertebrae with lateral ossification forming rudimentary ribs, thoracic vertebrae with rudimentary ribs, reduced ossification of ribs at the level of the thoracic vertebrae, lumbar vertebrae with lateral ossification with formation of supranumerary ribs, and lateral ossification of sacral vertebrae.

\section{Comet assay}

Table 6 shows the total number and mean number of lesioned cells distributed among the classes of DNA damage and the comet assay scores in peripheral blood samples of mice treated with the test compounds. Statistical analysis demonstrated that the 2 lower doses of 6-DMAP were not genotoxic. However, the mean number of lesioned cells increased by 23.11- 
fold when females treated with the highest dose of 6-DMAP were compared to females in the control group, thus demonstrating the genotoxic activity of the compound.

\begin{tabular}{|c|c|c|c|c|c|c|c|}
\hline \multirow[t]{2}{*}{ Treatment } & \multirow[t]{2}{*}{ Concentration } & \multirow[t]{2}{*}{ Lesioned cells } & \multicolumn{4}{|c|}{ Classes of damage } & \multirow[t]{2}{*}{ Score } \\
\hline & & & 0 & 1 & 2 & 3 & \\
\hline Control (PBS) & $0.1 \mathrm{~mL} / 10 \mathrm{~g}$ & $4.29 \pm 2.81^{\mathrm{a}}$ & $95.71 \pm 2.81$ & $4.29 \pm 2.81$ & $0.00 \pm 0.00$ & $0.00 \pm 0.00$ & $4.29 \pm 2.81^{\mathrm{a}}$ \\
\hline \multirow{3}{*}{ 6-DMAP } & $0.033 \mathrm{mg} / \mathrm{kg}$ & $8.29 \pm 4.79^{\mathrm{a}}$ & $91.71 \pm 4.79$ & $7.29 \pm 4.07$ & $1.00 \pm 0.82$ & $0.00 \pm 0.00$ & $9.29 \pm 5.53^{\mathrm{a}}$ \\
\hline & $0.33 \mathrm{mg} / \mathrm{kg}$ & $5.43 \pm 1.99^{\mathrm{a}}$ & $95.00 \pm 2.38$ & $4.71 \pm 2.05$ & $0.71 \pm 1.25$ & $0.00 \pm 0.00$ & $6.14 \pm 2.61^{\mathrm{a}}$ \\
\hline & $3.30 \mathrm{mg} / \mathrm{kg}$ & $99.14 \pm 1.57^{\mathrm{b}}$ & $0.86 \pm 1.57$ & $95.57 \pm 1.27$ & $3.57 \pm 2.37$ & $0.00 \pm 0.00$ & $102.71 \pm 3.81^{\mathrm{b}}$ \\
\hline \multirow[t]{3}{*}{ CHX } & $0.053 \mathrm{mg} / \mathrm{kg}$ & $97.28 \pm 1.70^{\mathrm{b}}$ & $2.71 \pm 1.70$ & $94.43 \pm 2.82$ & $2.86 \pm 2.48$ & $0.00 \pm 0.00$ & $100.14 \pm 3.18^{\mathrm{b}}$ \\
\hline & $0.53 \mathrm{mg} / \mathrm{kg}$ & $95.57 \pm 1.13^{\mathrm{b}}$ & $4.43 \pm 1.13$ & $92.14 \pm 2.48$ & $3.43 \pm 2.76$ & $0.00 \pm 0.00$ & $99.00 \pm 3.42^{\mathrm{b}}$ \\
\hline & $5.30 \mathrm{mg} / \mathrm{kg}$ & $97.14 \pm 2.41^{b}$ & $2.86 \pm 2.41$ & $90.71 \pm 2.21$ & $6.43 \pm 2.88$ & $0.00 \pm 0.00$ & $103.57 \pm 4.83^{\mathrm{b}}$ \\
\hline
\end{tabular}

${ }^{1}$ Mean number of injured cells in 700 cells examined (100 cells/animal). Different letters indicate statistically significant differences. Statistical test: analysis of variance/Tukey $(\mathrm{P}<0.05)$.

CHX was found to be genotoxic at all doses studied, and the amount of damage observed was increased by 22.68-, 22.28-, and 22.65-fold compared to controls at doses of $0.053,0.53$, and $5.30 \mathrm{mg} / \mathrm{kg}$ b.w., respectively. Evaluation of the comet scores led to a similar inference that the 2 lowest doses of 6-DMAP produced similar results to control values, while the highest dose was associated with a 23.94-fold increase. CHX produced statistically significant increases at all doses, which were 23.34-, 23.08-, and 24.14-fold for $0.053,0.53$, and $5.30 \mathrm{mg} / \mathrm{kg}$ b.w., respectively.

\section{Micronucleus test in peripheral blood}

The results form the evaluation of mutagenicity are presented in Table 7 and indicate that on the 7th gestational day (T1), $24 \mathrm{~h}$ after the first administration of the agents, the groups treated with the 2 lower doses of 6-DMAP showed higher micronuclei values. However, only the highest dose produced a significant mutagenic effect, and the frequency of micronuclei increased by 1.53 -fold compared to controls. All doses of CHX were found to be mutagenic, and the frequencies of micronuclei increased by 1.73-, 1.87-, and 1.56-fold for doses of $0.053,0.53$, and $5.30 \mathrm{mg} / \mathrm{kg}$ b.w. compared to the control group.

Table 7. Frequency of micronuclei in peripheral blood of mice treated with 6-dimethylaminopurine (6-DMAP) and cycloheximide (CHX).

\begin{tabular}{|c|c|c|c|c|c|}
\hline \multirow[t]{2}{*}{ Treatment } & \multirow[t]{2}{*}{ Concentration } & \multicolumn{2}{|c|}{ Total frequency of micronuclei ${ }^{1}$} & \multicolumn{2}{|c|}{ Means \pm standard deviation ${ }^{2}$} \\
\hline & & $7 \mathrm{dg}$ & $16 \mathrm{dg}$ & $7 \mathrm{dg}$ & $16 \mathrm{dg}$ \\
\hline Control (PBS) & $0.1 \mathrm{~mL} / 10 \mathrm{~g}$ & 77 & 73 & $11.00 \pm 3.16^{\mathrm{a}}$ & $10.43 \pm 2.37^{\mathrm{a}}$ \\
\hline \multirow[t]{3}{*}{ 6-DMAP } & $0.033 \mathrm{mg} / \mathrm{kg}$ & 90 & 102 & $12.86 \pm 2.85^{\mathrm{a}, \mathrm{b}}$ & $14.57 \pm 1.27^{\mathrm{a}, \mathrm{b}}$ \\
\hline & $0.33 \mathrm{mg} / \mathrm{kg}$ & 112 & 188 & $16.00 \pm 4.16^{\mathrm{a}, \mathrm{b}}$ & $26.86 \pm 3.34^{\mathrm{d}}$ \\
\hline & $3.30 \mathrm{mg} / \mathrm{kg}$ & 118 & 172 & $16.86 \pm 2.48^{b, c}$ & $24.57 \pm 3.55^{\mathrm{d}}$ \\
\hline \multirow{3}{*}{ CHX } & $0.053 \mathrm{mg} / \mathrm{kg}$ & 133 & 121 & $19.00 \pm 4.66^{\mathrm{b}, \mathrm{c}}$ & $17.29 \pm 3.68^{b, c}$ \\
\hline & $0.53 \mathrm{mg} / \mathrm{kg}$ & 144 & 146 & $20.57 \pm 0.79^{b, c}$ & $20.85 \pm 3.80^{\mathrm{c}, \mathrm{d}}$ \\
\hline & $5.30 \mathrm{mg} / \mathrm{kg}$ & 120 & 151 & $17.14 \pm 2.04^{b}$ & $21.57 \pm 3.21^{\mathrm{c}, \mathrm{d}}$ \\
\hline
\end{tabular}

${ }^{1}$ Frequency of micronuclei in 14,000 cells analyzed (2000 cells/animal). ${ }^{2}$ Mean number of micronuclei in 14,000 cells analyzed (2000 cells/animal). Different letters indicate statistically significant differences. Statistical test: analysis of variance/Tukey $(\mathrm{P}<0.05)$. 
Evaluations carried out on the 16th gestational day (T2), $24 \mathrm{~h}$ after 10 administrations of the test compounds, indicated mutagenic effects for the lowest dose of 6-DMAP tested and significant mutagenicity for the 2 higher doses. The increases in the frequency of micronuclei were $1.40,2.58$, and 2.36 for doses of $0.033,0.33$, and $3.30 \mathrm{mg} / \mathrm{kg}$ b.w., respectively. CHX showed a mutagenic effect at all doses tested, and the increases in micronuclei were 1.66, 2.00, and 2.07 times for doses of $0.053,0.53$, and $5.30 \mathrm{mg} / \mathrm{kg} \mathrm{b.w.,} \mathrm{respectively.}$

\section{DISCUSSION}

To better determine the capacity of compounds, such as 6-DMAP and CHX, to cause chromosomal alterations, abortions, teratogenesis, or any other type of developmental compromise in embryos produced by the nuclear transfer technique, clones should be produced and implanted in utero, followed by genetic toxicology analysis of mutagenesis and/or teratogenesis. However, because of the difficulties in obtaining a large number of clones and the high cost of such techniques, an alternative means of conducting this type of investigation is the administration of test compounds to pregnant females. This is not the most relevant study model for addressing these issues because the substances tested are often used in vitro. However, the effects of these compounds in relation to the reproductive performance of females and the embryonic development of their offspring after exposure can be evaluated. In addition, the proposed model, which is inexpensive and can be rapidly executed, may provide insight related to the low viability of mammals produced by nuclear transfer.

The results of this study demonstrate that the activating agents of oocyte cytoplasm, 6-DMAP and CHX, are genotoxic, mutagenic, and alter reproductive performance by increasing the rate of malformations in experimental animals. These findings are corroborated by the results of Hill et al. (1999) and Westhusin et al. (2001), who reported low survival, teratogenesis, and genetic alterations in cloned animals correlated with the use of 6-DMAP and CHX during their production.

The results of the present study showed that the administration of 6-DMAP and CHX was related to the occurrence of premature births and abortions, although the differences were not statistically significant. This has also been described in sheep, cattle, and goats, and the rates of fetal losses were as high as $50 \%$ for embryos derived from nuclear transfer using somatic or embryonic cells (Stice et al., 1996; Wells et al., 1997, 1999; Wilmut et al., 1997; Cibelli et al., 1998; Baguisi et al., 1999; Renard et al., 2002). Another important finding was that the viability of embryos produced by in vitro fertilization was 2-fold higher than viability of embryos conceived naturally (Heyman et al., 2002). However, in both cases, the alterations that appear to explain the gestational losses occurred at the placental level and involved the vascularization of extra-embryonic tissues (Walker et al., 1992; Hill et al., 1999; Wakayama and Yanagimachi, 1999; Renard et al., 2002). However, the present study showed no evidence of macroscopic alterations in the placenta or its vascularization. Therefore, the placental weight and placental index showed no significant differences. However, Renard et al. (2002) reported that alterations in the placenta were correlated with inadequate blood supply to the embryo, suggesting a pattern of malnutrition followed by death or retarded post-natal development. In this study, the fetuses of mothers treated with the highest dose of CHX were small for their gestational age and presented weights and lengths below the mean values. The highest dose of 6-DMAP tested was not associated with statistically significant differences related to fetal weight and length. However, the fetuses exhibited low weight for their gestational age. 
These findings indicate the need for histopathological studies of the placenta, as these offspring appeared to be malnourished.

Evaluation of maternal weight indicated that the animals began the experiments with similar weights, which were maintained through the beginning of gestation. However, the final weight, weight gain, and wet weight gain were lower for females treated with highest dose of CHX. Additionally, alterations were observed in the weights of the liver, kidneys, and lungs, indicating altered maternal metabolism. However, the experimental females showed no clinical symptoms of intoxication (e.g., opacity of the eyes and hair, drying out of mucosa, bristling of hair, alterations in behavior, morbidity, or decreased intake of water and/or food). The reductions observed in the final weight, weight gain, and wet weight gain can be explained by the reduced uterus weight. There were no significant differences in the number of implants or the number of live fetuses in these mice, though there were substantial differences in the number of reabsorptions and rates of post-implantation losses and reabsorptions. The fetuses observed with lower mean weights and lengths help account for this reduction.

The malformed fetuses observed, which mainly showed external abnormalities, generally presented a lower mean weight and length, indicating delays in embryonic and fetal development (Oliveira et al., 2009). In the present study, there was no correlation between reduced fetal weight and length and increased external malformations. Although no doseresponse relationship was observed, the highest dose of these compounds caused the highest frequency of alterations.

The rates of visceral malformations appeared to be high in all groups except for the control group, and the highest dose of CHX was associated with the highest frequency of malformations. With respect to skeletal malformations, the occurrence of alterations was high in all groups, including controls. This finding suggests that the alterations observed were variants of normal development and not necessarily malformations induced by the treatments and protocols under investigation here.

Various external, visceral, and skeletal malformations were observed in the different experimental groups, some of which have been previously reported following necropsy of stillborns and dead cloned mammals in the post-natal period (Hill et al., 1999).

It is known from genetic toxicology studies that congenital malformations can occur because of numeric and/or structural chromosomal alterations or alterations in gene expression. Teratogenic agents can also be genotoxic, aneugenic, and clastogenic and cause cell death, alter tissue growth, and interfere with cell differentiation and/or morphogenic processes (SchülerFaccini et al., 2003). In an attempt to better understand the dynamics of these phenomena, we conducted comet assays in samples collected $4 \mathrm{~h}$ after the first administration of the test compounds, which showed genotoxic activity for the highest dose of 6-DMAP and all doses of CHX tested. This genotoxic effect observed in the mothers can also occur in the offspring because the compounds can cross the placenta, causing malformations. With respect to the evaluation of mutagenicity, the micronucleus test for the 7th gestacional day showed an increased frequency of micronuclei in females treated with the highest dose of 6-DMAP and all doses of CHX, suggesting agreement between the comet and micronucleus assays. The data evaluated for these 2 assays indicate different alterations in DNA, and it is possible that the low frequency of injured cells observed in the micronucleus assay was because only a portion of the damage observed in the comet assay was permanent and, therefore, observed $20 \mathrm{~h}$ later in the micronucleus test. Non-permanent damage is thought to be repaired in an efficient manner through cellular repair systems. This is supported by earlier studies by Oliveira et al. (2006, 
2007), and other reports in the literature also refer to the comet assay as predictive of genotoxic damage that may or may not become mutations that can later be visualized as micronuclei. At the second time point evaluated in the micronucleus test, mutagenic activity was observed for the 2 higher doses of 6-DMAP and for all doses of CHX. The intermediate dose of 6-DMAP demonstrated a mutagenic effect at this time point, unlike at T1, suggesting an accumulation of cytogenetic damage after 10 days of exposure to the test agent. However, for other doses, there was no direct correlation between increased genetic damage and time of exposure.

The alterations responsible for the teratogenic events, such as cell death, alterations in the growth of tissue due to variations in the rates of mitosis and meiosis, interference with cell differentiation, and/or interference with morphogenic processes, may be explained by such cytotoxic, genotoxic, and mutagenic effects. According to Oliveira et al. (2014), when utilized at high doses, the compounds 6-DMAP and CHX were cytotoxic in vitro, genotoxic and mutagenic in vitro and in vivo and altered the nuclear division rate in vitro. These alterations can be explained, for example, by the effects of 6-DMAP on chromatin and microtubules, which are mediated by the inhibition of protein kinases and other enzymes involved in phosphorylation and dephosphorylation (Szöllösi et al., 1993; Rime et al., 1989, De La Fuente and King, 1988; Oliveira et al., 2014). The dephosphorylation caused by 6-DMAP can indirectly increase the rate of mitosis by activating mitogen-activated proteins (Verlhac et al., 1993, 1994; De La Fuente and King, 1998; Oliveira et al., 2014) and resulting in alterations of organogenesis.

The mitogenic action described above is supported by the results of Oliveira et al. (2014), who evaluated increases in mitogenic activity using the colorimetric thiazolyl blue tetrazolium bromide assay in HepG2 cells treated with 6-DMAP. These authors also reported an increased mitotic index using the micronucleus test, when the cells were treated with 0.01 $\mathrm{mg} / \mathrm{mL}$ 6-DMAP. The inhibitory activity resulting from the production of 6-DMAP kinases may have led to the increase observed in mitosis. These findings are supported the hypothesis of increased mitogenic activity described by Presicce and Yang (1994), Susko-Parrish et al. (1994), and De La Fuente and King (1998), who reported re-initiation of the cell cycle in bovine oocytes treated with $\mathrm{Ca}^{+2}, \mathrm{CHX}$, and 6-DMAP, resulting in high rates in the formation of blastocysts. However, Oliveira et al. (2014) demonstrated that high concentrations of these compounds in HepG2 cells can also delay the cell cycle, altering the nuclear division rate, which may help explain how such damage can lead to altered organogenesis. According to this previous study, alterations in the nuclear division rate either appear to be associated with mutagenic effects or were underestimated because of the incapacity of karyokinesis in the cells resulting from DNA damage, which compromises the normal course of mitosis in cells with a cytokinesis block in various somatic cell types. An elevated frequency of tetraploid metaphases in bovine embryos and the extrusion of 1-2 polar bodies containing chromatin result in losses of partial or whole chromosomes in Rhesus monkeys (De La Fuente and King, 1998; Mitalipov et al., 2001), which may indicate mitotic alterations, as noted earlier.

Oliveira et al. (2014) also demonstrated genotoxic and mutagenic activity in male mice in a protocol similar to that utilized in this study for the same compounds. The findings of Katoh et al. (2004) supported the hypothesis of mutagenicity of CHX by demonstrating its mutagenic activity in assays with Salmonella Typhimurium TA100, TA1535, TA98, TA1537, and Escherichia coli WP2 uvrA. Bhak et al. (2006) also demonstrated that 6-DMAP exposure was related to increased chromosomal abnormalities in embryos produced by nuclear transfer and that these abnormalities were associated with a reduced quality of development and/or viability. The present findings reinforce the results of De La Fuente and King (1998), who 
reported that the utilization of 6-DMAP and CHX was related to the successful production of clones in mammals, including cattle, rabbits, goats, and horses. However, despite showing satisfactory rates of oocyte activation, aneuploid cells were observed in embryos in addition to post-natal deaths, abortions, and congenital malformations.

Reports available describing alterations caused by compounds utilized for nuclear transfer to reconstitute embryos that contraindicate the process of cloning of mammals, as well as present a hypothesis explaining the low viability of cloned embryos. The results of this study corroborate these data and additionally indicate that 6-DMAP and CHX are linked to events that alter the reproductive performance of female mice, suggesting a correlation with teratogenic events and confirming the genotoxic and mutagenic capacity of these compounds. However, the data are not conclusive, and further studies are necessary. It will be necessary to evaluate the progeny (F1) of mothers treated with these compounds to determine their effects on fertility, as well as whether there are alterations in gamete segregation, thus suggesting the need for lethal dominant tests in males and teratogenic evaluations of the progeny of F1 females. Studies examining functional teratogenesis levels would be relevant for understanding physical and reflexological development and learning in the offspring of animals produced or treated with 6-DMAP and CHX.

\section{ACKNOWLEDGMENTS}

We thank Prof. Wilma de Grava Kempinas for her contributions to the editing of the manuscript. Research supported by Conselho Nacional de Desenvolvimento Científico e Tecnológico (CNPq), Coordenação de Aperfeiçoamento de Pessoal de Nível Superior (CAPES), and Fundação Araucária: Apoio ao Desenvolvimento Científico e Tecnologico do Paraná.

\section{REFERENCES}

Baguisi A, Behboodi E, Melican DT, Pollock JS, et al. (1999). Production of goats by somatic cell nuclear transfer. Nat. Biotechnol. 17: 456-461.

Barrow MV and Taylor WJ (1969). A rapid method for detecting malformations in rat fetuses. J. Morphol. 127: 291-305. Bhak JS, Lee SL, Ock SA, Mohana KB, et al. (2006). Developmental rate and ploidy of embryos produced by nuclear transfer with different activation treatments in cattle. Anim. Reprod. Sci. 92: 37-49.

Cibelli JB, Stice SL, Golueke PJ, Kane JJ, et al. (1998). Cloned transgenic calves produced from nonquiescent fetal fibroblasts. Science 280: 1256-1258.

Damasceno DC, Kempinas WG, Volpato GT and Consoni M (2008). Anomalias Congênitas: Estudos Experimentais. Coopmed Editora Médica, Belo Horizonte.

De La Fuente R and King WA (1998). Developmental consequences of karyokinesis without cytokinesis during the first mitotic cell cycle of bovine parthenotes. Biol. Reprod. 58: 952-962.

Haseman JK and Hogan MD (1975). Selection of the experimental unit in teratology studies. Teratology 12: 165-171.

Hayashi M, Morita T, Kodama Y, Sofuni T, et al. (1990). The micronucleus assay with mouse peripheral blood reticulocytes using acridine orange-coated slides. Mutat. Res. 245: 245-249.

Heyman Y, Chavatte-Palmer P, LeBourhis D, Camous S, et al. (2002). Frequency and occurrence of late-gestation losses from cattle cloned embryos. Biol. Reprod. 66: 6-13.

Hill JR, Roussel AJ, Cibelli JB, Edwards JF, et al. (1999). Clinical and pathologic features of cloned transgenic calves and fetuses (13 case studies). Theriogenology 51: 1451-1465.

Katoh M, Araki A, Ogura T and Valdivia RP (2004). 6-Dimethylaminopurine (6-DMAP), which is used to produce most cloned animals, is mutagenic in Salmonella typhimurium TA1535. Mutat. Res. 560: 199-201.

Kobayashi H, Sugiyama C, Morikawa Y and Hayashi M (1995). A comparison between manual microscopic analysis and computerized image analysis in the single cell gel electrophoresis assay. MMS Commun. 2: 103-115.

Manson JM, Zenick H and Costlow RD (1982). Teratology Test Methods for Laboratory Animals. In: Principles and 
Methods of Toxicology (Hayves AW, ed.). Raven Press, New York.

Manson JM and Kang YJ (1994). Test Methods for Assessing Female Reproductive and Developmental Toxicology. In: Principles and Methods of Toxicology (Hayves AW, ed.). Raven Press, New York.

Mitalipov SM, Nusser KD and Wolf DP (2001). Parthenogenetic activation of rhesus monkey oocytes and reconstructed embryos. Biol. Reprod. 65: 253-259.

Oliveira RJ, Ribeiro LR, da Silva AF, Matuo R, et al. (2006). Evaluation of antimutagenic activity and mechanisms of action of beta-glucan from barley, in CHO-k1 and HTC cell lines using the micronucleus test. Toxicol. In Vitro 20: 1225-1233.

Oliveira RJ, Matuo R, da Silva AF, Matiazi HJ, et al. (2007). Protective effect of beta-glucan extracted from Saccharomyces cerevisiae, against DNA damage and cytotoxicity in wild-type (k1) and repair-deficient (xrs5) CHO cells. Toxicol. In Vitro 21: 41-52.

Oliveira RJ, Salles MJ, da Silva AF, Kanno TY, et al. (2009). Effects of the polysaccharide beta-glucan on clastogenicity and teratogenicity caused by acute exposure to cyclophosphamide in mice. Regul. Toxicol. Pharmacol. 53: 164-173.

Oliveira RJ, Mantovani MS, da Silva AF, Pesarini JR, et al. (2014). Compounds used to produce cloned animals are genotoxic and mutagenic in mammalian assays in vitro and in vivo. Braz. J. Med. Biol. Res. 47: 287-298.

Presicce GA and Yang X (1994). Nuclear dynamics of parthenogenesis of bovine oocytes matured in vitro for 20 and 40 hours and activated with combined ethanol and cycloheximide treatment. Mol Reprod. Dev. 37: 61-68.

Renard JP, Zhou Q, LeBourhis D, Chavatte-Palmer P, et al. (2002). Nuclear transfer technologies: between successes and doubts. Theriogenology 57: 203-222.

Rime H, Neant I, Guerrier P and Ozon R (1989). 6-Dimethylaminopurine (6-DMAP), a reversible inhibitor of the transition to metaphase during the first meiotic cell division of the mouse oocyte. Dev. Biol. 133: 169-179.

Salewski E (1964). Färbemethoden zum makroskopischen nachweis von implantationsstellen am uterus der ratte. NaunymSchmiedeberg Archiv. Exp. Pathol. Pharmkol. 247: 367.

Schüler-Faccini L, Leite JCL and Peres RM (2003). Teratogênese e Ambiente. In: Genética Toxicológica (Silva J, Erdtmann B and Henriques JAP, eds.). Editora Alcance, Porto Alegre, 387-403.

Singh NP, McCoy MT, Tice RR and Schneider EL (1988). A simple technique for quantitation of low levels of DNA damage in individual cells. Exp. Cell Res. 175: 184-191.

Staples RE and Schnell VL (1964). Refinements in rapid clearing technic in the koh-alizarin red s method for fetal bone. Stain Technol. 39: 61-63.

Stice SL, Strelchenko NS, Keefer CL and Matthews L (1996). Pluripotent bovine embryonic cell lines direct embryonic development following nuclear transfer. Biol. Reprod. 54: 100-110.

Susko-Parrish JL, Leibfried-Rutledge ML, Northey DL, Schutzkus V, et al. (1994). Inhibition of protein kinases after an induced calcium transient causes transition of bovine oocytes to embryonic cycles without meiotic completion. Dev. Biol. 166: 729-739.

Szöllösi MS, Kubiak JZ, Debey P, de Pennart H, et al. (1993). Inhibition of protein kinases by 6-dimethylaminopurine accelerates the transition to interphase in activated mouse oocytes. J. Cell Sci. 104 (Pt 3): 861-872.

Taylor P (1986). Pratical Teratology. Academic Press, New York.

Tice RR, Agurell E, Anderson D, Burlinson B, et al. (2000). Single cell gel/comet assay: guidelines for in vitro and in vivo genetic toxicology testing. Environ. Mol. Mutagen. 35: 206-221.

Verlhac MH, de PH, Maro B, Cobb MH, et al. (1993). MAP kinase becomes stably activated at metaphase and is associated with microtubule-organizing centers during meiotic maturation of mouse oocytes. Dev. Biol. 158: 330-340.

Verlhac MH, Kubiak JZ, Clarke HJ and Maro B (1994). Microtubule and chromatin behavior follow MAP kinase activity but not MPF activity during meiosis in mouse oocytes. Development 120: 1017-1025.

Wakayama T and Yanagimachi R (1999). Cloning of male mice from adult tail-tip cells. Nat. Genet. 22: 127-128.

Walker SK, Heard TM and Seamark RF (1992). In vitro culture of sheep embryos without coculture: successes and perspectives. Theriogenology 37: 111-126.

Wells DN, Misica PM, Day TA and Tervit HR (1997). Production of cloned lambs from an established embryonic cell line: a comparison between in vivo- and in vitro-matured cytoplasts. Biol. Reprod. 57: 385-393.

Wells DN, Misica PM and Tervit HR (1999). Production of cloned calves following nuclear transfer with cultured adult mural granulosa cells. Biol. Reprod. 60: 996-1005.

Westhusin ME, Long CR, Shin T, Hill JR, et al. (2001). Cloning to reproduce desired genotypes. Theriogenology 55: 35-49. Wilmut I, Schnieke AE, McWhir J, Kind AJ, et al. (1997). Viable offspring derived from fetal and adult mammalian cells. Nature 385: 810-813.

Wilson JG (1965). Methods for Administering Agents and Detecting Malformations in Experimental Animals. In: Teratology: Principles and Techniques (Wilson JG and Warkany J, eds.). The University of Chicago Press, Chicago. 